\title{
Subjective and objective determinants of the satisfaction from the cooperation in a dance couple
}

\begin{abstract}
BACKGROUND
Dance is an extremely complicated sports discipline, which combines features of the "original" form of dance associated with the expression of self and one's emotions while maintaining the qualities of a competitive sport. It is particularly important for the cooperation of a couple to develop a relationship during training so that the partners feel satisfaction from working with each other, but are also pleased with the results in the discipline in which they train.

The aim of this study was to analyse the factors responsible for the satisfaction with cooperation in a couple, which included, among other things, the dance level, degree of involvement and responsibility of each partner for the development of the couple.
\end{abstract}

\section{PARTICIPANTS AND PROCEDURE}

The study involved 30 dance couples aged 13-26 years $(M=16.48, S D=2.16)$. Participants completed two questionnaires (Own Poll and the Dyadic Trust Scale [DTS]) and provided demographic information in a quiet environment, usually at their education or training facilities.

\section{RESULTS}

The results indicated the importance of their own and perceived partner involvement in the development of the couple for the satisfaction from the success in the sport. It is surprising, however, that the results reveal no association between dance experience and satisfaction of practising sport analysed in the study.

\section{CONCLUSIONS}

Satisfaction plays an important role in relationships of pair dancers. In dancing, satisfaction may derive from subjective rather than objective factors, mainly those related to the relationship in the couple.

KEY WORDS

dancing; relationship; cooperation

ORganizations - Institute of Psychology, University of Gdansk, Gdansk, Poland

authors' Contribution - A: Study design - B: Data collection - C: Statistical analysis - D: Data interpretation .

E: Manuscript preparation · F: Literature search · G: Funds collection

Corresponding Author - Dagmara Budnik-Przybylska, Ph.D., Institute of Psychology, University of Gdansk,

4 Bażyńskiego Str., 80-952 Gdansk, Poland, e-mail: psydbu@univ.gda.pl

to Cite this ARTICLE - Budnik-Przybylska, D., Lewandowska-Walter, A., \& Czyżyk, P. (2015). Subjective and objective

determinants of the satisfaction from the cooperation in a dance couple. Health Psychology Report, 3(1), 35-46.

DOI: $10.5114 /$ hpr.2015.48989 


\section{BACKGROUND}

Generally, dancing is mainly regarded as a form of art, as originally it was related to expressing emotions. In the last 20 years, this situation has been changing in favour of perceiving dance, especially ballroom dance, as a competitive sport. Dancing can be defined as an orderly movement of the body to the rhythm of music. Dancing has accompanied mankind virtually since the beginning, as it is one of our natural needs. Initially, primitive man would dance to express emotions, which was associated with the presence of shouts and singing. That is how chorea, a specific form of human expression which a few thousand years later was proclaimed art, came into existence. Through primitive movements, words and melody, men gained a deeper understanding of nature (Tomaszewski, 1991). In the early civilizations the body and the psyche were not considered to be two distinct entities. Everything that happened around men evoked a deep emotional response within them. A particular role of dancing can be observed in primitive religions, where it constituted a part of rites (Eliade, 2009). Movement rituals were a link between man and the environment he lived in. The objective of dancing was to reduce emotional tension that accompanied particular emotions, both positive and negative (Darwin, 1972; Spencer, 1955). In its evolution, dancing underwent quite a long period of development, during which the perception of dancing changed considerably.

In the $20^{\text {th }}$ century there was an attempt to systematize our knowledge about dancing in European culture. That systematization took into account the diversity of dance in terms of place of origin, its nature and the social class in which it was performed. During that period, for the first time attention was drawn to the individual nature of dance, as well as to the dancer, who is driven by motivations that allow them to render their state of mind. The dancer's inner self and what they feel together with the music became an inspiration for dance. To this day, this approach is recognized by modern dancers.

The first half of the $20^{\text {th }}$ century, aside from the already well-known dances (both aristocratic and folk) introduced new dance forms such as expressive, liberated, contemporary jazz and stage dance, as well as rhythmic gymnastics. Dancing came to be a very common phenomenon, often regarded as entertainment or a form of spending free time. The culture of dance also changed. Previously repressed behaviour began to gain acceptance. One example is the Viennese Waltz, formerly disregarded due to the partners embracing (men and women) while dancing.

\section{DANCE AS A SPORTS DISCIPLINE}

Today, dance is an extremely complex sport, which combines the characteristics of the "primitive" form of dance associated with expressing oneself and one's emotions with the characteristics of a competitive sport that presents a particular technique or a configuration of figures while engaging one's muscular apparatus (Bednarzowa \& Młodzikowska, 1983).

Ballroom dancing has become extremely popular. Dancesport can be described as a non-standard movement, in which the movement scheme is generally defined, cyclic and acyclic and characterized by variable intensity and great dynamics (Fostiak, 1996). Dancers should demonstrate many abilities including highly developed coordination, kinaesthetic abilities to differentiate movement, a sense of balance, a sense of rhythm, as well as quick motor responses. The beauty of ballroom dance also derives from the fact that the dancers partner each other. Fostiak (1996) stated that in ballroom dance there is a phenomenon of "feeling your partner". It is a mutual contact of the torso and the hands, whose aim is to lead the female dancer, to which she responds with proper movements. "The feel of your partner" depends on the level of motor coordination, training, emotions, external factors and one's technique. Partners affecting each other during movement allows for various lines to form in a natural way, which then produce extremely spectacular images of the pair. Those images combined with music evoke positive impressions in the viewer.

In ballroom dancesport, ten dances, performed in two dance styles, are distinguished. Standard style consists of the following dances: the Waltz, Tango, Viennese Waltz, Slow Foxtrot, and Quickstep. Latin style comprises: Samba, Cha-Cha-Cha, Rumba, Paso Doble, and Jive. Every style is characterized by common qualities of the particular dances that allow for their inclusion in the proper style, as well as by some differentiating features. The common element for the standard style may be the position of the partners in relation to one another. Partners are facing each other; they dance in contact (close to each other). Leading in a pair is reserved for the man, while the woman reacts to his moves. They pursue one direction. It is possible due to the compatibility of the moves of the partners who dance in a particular dance rhythm. The common quality of the standard style that separates it from the Latin style is the "frame", unchanged during the dance, as well as dance costumes - a long dress for the woman and a tailcoat for the man. In the Latin style the "frame" is not needed for leading and, as a consequence, dance figures can be performed by the partners separately.

Nowadays, dance aspires to become an Olympic sport. Dancesport has particular rules. According to the rules of the Polish Dance Association (Polskie Towarzystwo Taneczne, PTT) there are three lower classes - E, D, C - where the dance technique, the execution of particular figures, figure combinations, rhythmicity and the dancers' ear for music are rat- 
ed by the judges (adjudicators). Dancers of the lower classes have a clearly defined and limited repertoire of figures they can perform. Costumes in these classes cannot be decorated with any embellishments such as stones, sequins or feathers. In the upper classes - B, A, S ( $\mathrm{S}$ is the highest, international dance class) - in addition to the technique and execution, expression and charisma of the dancers, interpretation of the dances, and the ability to present oneself on the dance floor are also rated.

\section{RELATIONSHIP DYNAMICS AND SATISFACTION DERIVED FROM THE COOPERATION IN A DANCE COUPLE}

The relation that develops in a dance couple is hard to define. Undoubtedly, it is a very close relationship - both in the physical dimension, as mentioned earlier, and in the personal dimension, while at the same time it has characteristics of a rapport typical for the work environment. As it turns out, in the case of dancesport dancers, the professional and personal levels of the relationship often coexist - dance partners define each other as best friends (Wanlin, 2000), and frequently they are also life partners (Brewińska \& Poczwardowski, 2010).

Applying Reisman's (1981) typology of friendship, one can state that paired up dancers at the beginning of their sports path develop an associative friendship, that is they meet in order to reach the same objective, which brings them closer together. However, what can be observed in many dance couples is that with time partners become increasingly involved in a relationship which begins to be reciprocal, both on an emotional level and in terms of their engagement in the couple's development. Kram and Isabella (1985) proposed similar types of professional relationship - in terms of a dance couple, what can be observed is a transformation from a relationship based on work-related communication to a relationship (information peer) in which emotional closeness and trust that goes beyond the professional sphere are present (special peer). A close relationship in a couple is characterized by a high level of intimacy, trust and involvement (Fisher \& Adams, 1994), as well as reciprocity (Reisman, 1981). Therefore, what is important for the satisfaction derived from the relationship are the quality of one's functioning in a couple and one's individual well-being, as well as noticing the partner's involvement and their responsibility for the couple's development (Kaźmierczak, 2008). At the same time, the resource exchange observed between partners in a relationship is uneven (Sprecher, 1992; Fincham \& Bradbury, 1989).

Men and women differ in terms of the level of responsibility for what happens in a couple and, as a consequence, also in terms of the satisfaction they derive from functioning in a relationship (Plopa, 2004). Mutual trust, as Johnson and Talisman (1996) conclude, may be of greater importance for the level of satisfaction in a relationship in the case of women than men.

Without a doubt, the continual collaboration between a man and a woman in ballroom dancing is an extremely interesting phenomenon. It is essential that the partners reach compromises so that they can derive satisfaction not only from working together but also from the discipline they practise. The satisfaction and pleasure that come from doing sports is one of the six factors responsible for one's desire to develop sports skills and affirm one's commitment to training

The Sport Commitment Model (SCM) proposed by Scanlan, Carpenter, Schmidt, Simons, and Keeler (1993) is a generally accepted theoretical framework for understanding the process of young dancers' development in sports (see e.g. Yin Chu \& Wang, 2012). The inspiration for creating such a model was the social exchange theory (Kelley \& Thibaut, 1978), as well as the romantic relationship model (Kelley, 1983) and the investment model (Rusbult, 1980, 1983). That model states that the determinants responsible for the involvement in sports are, aside from the aforementioned sport enjoyment, involvement alternatives, personal investment in the sport (time, effort, money), social constraints and obligations, benefits gained from doing the sport (involvement opportunities) and social support (Scanlan et al., 1993). Factors accountable for the extent of involvement in dancesport can differ from those in other disciplines due to the physical connection between partners and the constant work in a twosome (Yin Chu \& Wang, 2012). In this case, the engagement can also be interpreted as a desire to sustain the rapport between partners on a sports level, as well as on an interpersonal level.

Tremayne and Ballinger (2008) emphasise that the basis of dance lies in the communication that contributes to the development of a mutual trust. Trust, on the other hand, is a vital component responsible for the success in building a relationship (Sharabany, 1994; Cole \& Bradac, 1996) and deriving satisfaction from it (Argyle \& Henderson, 1984; Johnson \& Talisman, 1996), including in dance couples (Wanlin, 1998, 2000). Mutual trust can be developed by practising communication skills (Reuna, Weich, \& Zimmer, 1984). Likewise, the level of cohesion in a team is related to the athletes' satisfaction and their achievements (Steiner, 1972; Anshel, 1994). Cohesion is defined as a level of intimacy, sense of unity and the strength of the emotional bonds between members of a group. When considering dance partners, synergy can be explained as an "interaction of the efforts of two or more individuals, which amounts to more than the sum of their respective strengths" (Mears \& Voehl, 1994, p. 4).
Determinants of the satisfaction in a dance couple 
Dagmara

Budnik-Przybylska,

Aleksandra

Lewandowska-

Walter,

Paulina Czyżyk
According to Carron (1980), a cohesive team allows one to predict success in fulfilling tasks, which promotes satisfaction from collective accomplishments. Partners who represent the "we"-type orientation have better chances for overcoming both technical difficulties and interpersonal blockage that arise during training than dancers who are self-oriented or concentrated only on their partner (Cahn, 1987; Hawes \& Smith, 1973). "Team orientation" promotes seeking compromise and resolving issues that emerge in a couple.

Sports experience and dance classes are the objective determinants that can be responsible for the degree of satisfaction derived from working in pairs. Studies on engagement in sport (Schmidt \& Stein, 1991) have shown that budding sportsmen pursue further training because of the enjoyment, whereas in later stages the commitment, which is still accompanied by positive emotions, though to a lesser extent, gains momentum.

Additionally, sports experience is also relevant to the degree of involvement in workouts in the case of dancers and for the sense of fulfilment from the practised discipline. Yin Chu and Wang (2012) proved that although the more experienced dancers were more engaged and achieved better results in terms of their own investments in sports, at the same time they had fewer alternatives and derived less pleasure from dancing than the less experienced dancers. Therefore, trainers and psychologists should sustain the joy obtained from sports in such a way that it counteracts the obstacles that come with perfecting dance technique and thus reduce the risk of young dancers suffering from "occupational burnout" or quitting practice.

The aim of this study was to evaluate subjective and objective indicators of satisfaction with cooperation in the dance couple.

\section{PARTICIPANTS AND PROCEDURE}

\section{PARTICIPANTS}

Thirty dance couples aged 13-26 years $(M=16.48$, $S D=2.16)$.

\section{PROCEDURE OF STUDY}

Written consent was obtained from athletes over 18 years, and a parent or person with care responsibilities in the case of minors. The treatment of athletes was in accordance with American Psychological Association (APA) ethical guidelines. Participants completed the questionnaires and provided their demographic information in a quiet environment, usually at their education or training facilities. Participants completed the materials individually or in small groups and then returned them to the investigators. Data collection took approximately $20 \mathrm{~min}$ utes. The statistical analysis of the collected results was conducted using SPSS for Windows 21.0.

The comparison of averages with $t$ test, Pearson's correlation coefficient $(r)$ and regression analysis were used in the calculations.

\section{MEASURES}

Own poll: demographics and characteristics of dance couple (training class), satisfaction with cooperation, the distance in the relationship with the partner and with others, commitment and responsibility for the development of the couple (Appendix).

The Dyadic Trust Scale (DTS) (Larzelere \& Huston, 1980), consisting of eight items, has been found to be a reliable measure of belief in a partner's benevolence and honesty. The instructions of the scale have been adapted to the requirements of this study. The measure, though only eight items long, has been found to be a reliable measure of the belief in a partner's benevolence and honesty. The $\alpha$ coefficient for internal consistency of the DTS in the present study is .93.

\section{RESULTS}

In this study, the following determinants of satisfaction with the cooperation of a dance couple were chosen:

- objective variables: training period, dance class in standard and Latin styles, the period of training with each other;

- subjective variables: involvement, responsibility for the development of the couple, the satisfaction with progress, trust in the couple, the closeness of the relationship in the couple.

During the first stage the results of men and women were compared by the perceived satisfaction in the couple. No significant difference was observed between the dancing men and women for this variable (female: $M=6.87, S D=2.13$, male: $M=7.17, S D=1.78$, $F=1.35, p=$ insignificant, $t=-0.59, p=$ insignificant).

Next, an analysis of the correlation of objective and subjective variables of satisfaction in the couple was performed - first on the whole group and then divided by sex.

In the analysis of the correlation of objective variables and satisfaction in the couple for the entire group, the level in standard style, the period of training in general and the period of training with the current partner turned out to be statistically insignificant, while the level of the class in Latin style was important. The lower was the class in LA, the greater was the satisfaction with cooperation with the dance partner $(r=-.33, p=.011)$. 
Table 1

Correlations of satisfaction in the couple and objective variables - the results for the entire group and divided by gender

\begin{tabular}{|c|c|c|c|c|c|}
\hline & & Class-ST & Class-LA & $\begin{array}{l}\text { Training period } \\
\text { in general }\end{array}$ & $\begin{array}{c}\text { Training period with } \\
\text { current partner }\end{array}$ \\
\hline $\begin{array}{l}\text { Satisfaction } \\
\text { entire group }\end{array}$ & $\begin{array}{c}\text { Pearson } \\
\text { correlation }\end{array}$ & .10 & $-.33^{*}$ & .00 & -.13 \\
\hline $\begin{array}{l}\text { Satisfaction } \\
\text { female }\end{array}$ & $\begin{array}{c}\text { Pearson } \\
\text { correlation }\end{array}$ & .20 & -.44 & .03 & -.03 \\
\hline $\begin{array}{l}\text { Satisfaction } \\
\text { male }\end{array}$ & $\begin{array}{c}\text { Pearson } \\
\text { correlation }\end{array}$ & -.02 & -.17 & -.06 & -.26 \\
\hline
\end{tabular}

Note. ${ }^{*} p<.050$

Then an analysis of the correlation of objective variables and satisfaction in the couple was performed. The analysis of correlation of objective variables and satisfaction in the couple for women showed that, similar to the whole group, the only significant correlation was observed in the case of class in LA. The lower was the class in LA, the greater was the satisfaction in the dance couple $(r=-.44, p=.017)$. For men, none of the objective variables correlated significantly with satisfaction in the couple (Table 1).

Subsequent analysis focused on the correlation of satisfaction in the couple with psychological variables such as: perceived own and partner's involvement in the development of the couple, the perceived own and partner's responsibility for the development of the couple, the satisfaction with the progress, the trust in the couple as well as the closeness of the relationship in the couple.

In the whole group all psychological variables, except own responsibility for the development of the couple (the result was statistically insignificant), correlated positively and significantly with satisfaction in the couple: the closeness of the relationship in the couple $(r=.62$, $p<.001)$, the trust in the couple $(r=.56, p<.001)$, satisfaction with progress $(r=.55, p<.001)$, engagement of a partner in the development of the couple $(r=.52$, $p<.001)$, partner's responsibility for the development of the couple ( $r=.44, p=.001)$, and own involvement in the development of a couple $(r=.33, p=.010)$.

In the case of women, the following correlations with satisfaction in the couple were found to be significant with such psychological variables as: partner's involvement in the development of the couple $(r=.68, p<.001)$, satisfaction with progress $(r=.63, p<.001)$, the closeness of the relationship in the couple $(r=.61, p<.001)$, trust in the couple $(r=.54$, $p=.002)$ and the own involvement in the development of the couple $(r=.43, p=.016)$. There was no correlation of satisfaction in the couple with the responsibility (both own and partner's) for the development of the couple.

For men, there were correlations of satisfaction in the couple with psychological variables such as part- ner's responsibility for the development of the couple ( $r=.63, p<.001)$, closeness of the relationship in the couple $(r=.62, p<.001)$, trust in the couple $(r=.59$, $p=.001)$, satisfaction with progress $(r=.43, p=.018)$, own involvement in the development of the couple ( $r=.37, p=.046)$ and partner's involvement in the development of the couple $(r=.37, p=.047)$. For men, the partner's responsibility for the development of the couple reached the highest value, while for women this correlation was insignificant (Table 2).

An analysis of regression was performed, in which the predictors of satisfaction in the couple were both objective and subjective variables (Table 3 ).

The following objective variables were selected as potential predictors of satisfaction in the couple: the level in standard style, the level in Latin style, training period in general and training period with current partner. The results of regression analysis showed that among the explanatory variables included in the regression equation, the level in Latin style was the strongest predictor of satisfaction in the couple.

For women only the dance level in Latin proved to be a significant predictor. In the case of men, objective variables were found to be significant predictors. This model accounted for $26 \%$ of the total variance (Table 4).

Regression analysis was also performed, where subjective variables were selected to be predictors of satisfaction in the couple: own involvement in the development of the couple, partner's involvement in the development of the couple, own responsibility for the development of the couple, partner's responsibility for the development of the couple, satisfaction with progress, the closeness of the relationship in the couple and the trust in the couple.

For women, the strongest predictor of satisfaction in the couple proved to be satisfaction with progress $(\beta=.41, p=.012)$. The whole model accounted for $62 \%$ of the total variance. For the men it proved to be respectively: partner's responsibility for the development of the couple $(\beta=.47, p=.024)$ and then own involvement in the development of the couple
Determinants of the satisfaction in a dance couple 
Table 2

Correlations of satisfaction in couple and subjective variables - results for the entire group and divided by gender

\begin{tabular}{|c|c|c|c|c|c|c|c|c|c|}
\hline \multirow{4}{*}{$\begin{array}{r}\text { Dagmara } \\
\text { Budnik-Przybylska, } \\
\text { Aleksandra } \\
\text { Lewandowska- } \\
\text { Walter, } \\
\text { Paulina Czyżyk }\end{array}$} & & & 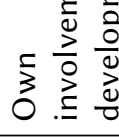 & 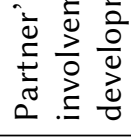 & 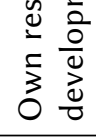 & 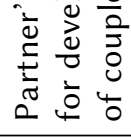 & 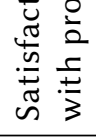 & $\begin{array}{l}.5 \\
\frac{n}{2} \\
\frac{n}{2}\end{array}$ & 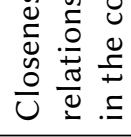 \\
\hline & Satisfaction & $\begin{array}{c}\text { Pearson } \\
\text { correlation }\end{array}$ & $.33^{* *}$ & $.52^{* *}$ & .25 & $.44^{* *}$ & $.55^{* *}$ & $.56^{* *}$ & $.62^{* *}$ \\
\hline & $\begin{array}{l}\text { Satisfaction } \\
\text { female }\end{array}$ & $\begin{array}{c}\text { Pearson } \\
\text { correlation }\end{array}$ & $.43^{*}$ & $.68^{* *}$ & .32 & .34 & $.63^{* *}$ & $.54^{* *}$ & $.61^{* *}$ \\
\hline & $\begin{array}{l}\text { Satisfaction } \\
\text { male }\end{array}$ & $\begin{array}{c}\text { Pearson } \\
\text { correlation }\end{array}$ & $.37^{*}$ & $.37^{*}$ & 0.14 & $.63^{* *}$ & $.43^{*}$ & $.59^{* *}$ & $.62^{* *}$ \\
\hline
\end{tabular}

Note. ${ }^{*} p<.050,{ }^{* *} p<.010$

Table 3

Results of regression analysis for satisfaction in couple and objective variables

\begin{tabular}{|c|c|c|c|c|}
\hline \multicolumn{5}{|c|}{$R=.61, R^{2}=.38$, adjusted $R^{2}=.26, F(4,28)=3.60, p<.001$} \\
\hline & Variables & $\beta$ & $t$ & $p$ \\
\hline \multirow{4}{*}{ Female } & Class-ST & .36 & 1.73 & .097 \\
\hline & Class-LA & -.68 & -3.41 & .002 \\
\hline & training period in general & .19 & 0.82 & .421 \\
\hline & training period with current partner & -.12 & -0.72 & .479 \\
\hline \multicolumn{5}{|c|}{$R=.32, R^{2}=.10$, adjusted $R^{2}=-.05, F(4,28)=0.67, p=$ n.i. } \\
\hline \multirow{4}{*}{ Male } & Class-ST & .14 & 0.56 & .580 \\
\hline & Class-LA & -.19 & -0.84 & .409 \\
\hline & training period in general & .00 & -0.02 & .987 \\
\hline & training period with current partner & -.26 & -1.32 & .199 \\
\hline
\end{tabular}

$(\beta=-.34, p=.039)$. The whole model accounted for $64 \%$ of the total variance.

\section{DISCUSSION}

Dancesport is a specific sport. Without a doubt the constant cooperation of man and woman is interesting. Especially in the field of partners' cooperation it is essential to develop a compromise for the couple to feel satisfaction with the cooperation with each other, but also to feel satisfaction from the discipline in which they train.
The aim of this study was to investigate the determinants of satisfaction in the dance couple. We divided them into objective and subjective factors:

- objective variables: training period, dance class in standard and Latin styles, the period of training with each other;

- subjective variables: involvement, responsibility for the development of the couple, satisfaction with progress, trust in the couple, closeness of the relationship in the couple.

The following analyses were carried out sequentially: the comparison of satisfaction in the couple of men and women, afterwards the correlation between 


\begin{tabular}{|c|c|c|c|c|}
\hline \multicolumn{5}{|c|}{$R=.84, R^{2}=.71$, adjusted $R^{2}=.62, F(7,29)=7.75, p<.001$} \\
\hline \multirow{8}{*}{ Female } & & $\beta$ & $t$ & $p$ \\
\hline & closeness of relationship in coupl & .28 & 1.83 & .081 \\
\hline & own involvement in development of couple & .07 & 0.37 & .716 \\
\hline & partner's involvement in development of couple & .19 & 0.71 & .485 \\
\hline & own responsibility for development of couple & .37 & 1.69 & .106 \\
\hline & partner's responsibility for development of couple & -.14 & -0.59 & .562 \\
\hline & satisfaction with progress & .41 & 2.72 & .012 \\
\hline & scale of trust in couple & .10 & 0.54 & .596 \\
\hline \multicolumn{5}{|c|}{$R=.85, R^{2}=.73$, adjusted $R^{2}=.64, F(7,28)=8.07, p<.001$} \\
\hline \multirow{7}{*}{ Male } & closeness of relationship in couple & .13 & 0.75 & .465 \\
\hline & own involvement in development of couple & .29 & 1.76 & .092 \\
\hline & partner's involvement in development of couple & -.01 & -0.06 & .955 \\
\hline & own responsibility for development of couple & -.34 & -2.20 & .039 \\
\hline & partner's responsibility for development of couple & .47 & 2.44 & .024 \\
\hline & satisfaction with progress & .23 & 1.26 & .221 \\
\hline & scale of trust in couple & .21 & 1.26 & .221 \\
\hline
\end{tabular}

objective and subjective variables of satisfaction in the couple was analysed, and finally a regression analysis was performed, in which predictors of satisfaction in the couple were successively objective and subjective variables.

No differences were noted between men and women as regards perceived satisfaction in the couple. Discrepancies in this field could cause quarrels and in consequence a breakup of the couple; therefore the obtained result supports the thesis that dancing means a close relationship between partners. The result may also suggest that it is important for a dance pair to achieve a similar level of satisfaction of cooperation to be engaged in training no matter whether it is an associative friendship or a reciprocal relationship (see: Reisman, 1981). A lack of differences in the level of satisfaction does not mean that dance partners do not differ in factors that influence how much they are content with cooperation, as was shown by other analysis in the present study.

Analysing the results of the correlation of objective factors with satisfaction, it is surprising that the results show no association between training period and satisfaction of practising the discipline analysed in the study. This result is consistent with the statement that it is essential that the partners reach compromises so that they can derive satisfaction not only from working together but also from the discipline they practise. It means that not the time but the satisfying relationship with the partner from the team is important. The result supports the conclusions of Yin Chu and Wang (2012) - it is important for trainers to work not only on improving the technique but also to work on the relationship between dancers working in a pair from the very beginning of their training.

For men, none of the objective variables are related to the satisfaction with the couple's progress, while for women only the dance level in Latin negatively correlated with this variable. This may mean that these athletes do not yet have high knowledge of the discipline, they experience pleasure from what they do, and they feel better than their non-dancing counterparts. At higher grades cooperation in the couple is more complex.

Similarities and differences in the factors that correlate with satisfaction in the couple in the case of women and men were observed. In both groups of dancers closeness of the relationship in the couple is associated positively and highly with satisfaction (women: $r=.61$, men: $r=.62$ ), which means that the closer the partners are to each other in general, the more satisfied they are with the cooperation of the couple.

Ballroom dancing is a complicated and unique discipline, as it is among the few disciplines in sport (along with ice skating in pairs and ice dancing) where a man and a woman need to constantly work with each other. They have to work together in close physical proximity for competitive purposes. But before the actual competition, they have to spend a lot of time together during training sessions, which is
Determinants of the satisfaction in a dance couple 
why this sport requires a very intimate relationship between the couple. The need to constantly be with each other, to cooperate, to travel to competitions. All of this, mainly in the competitive sport, points to the relationship between a couple similar to the relationship in a marriage. This is due, in part, to the commitment and dedication needed to excel in the sport. Partners must exhibit passion and emotion during dancing. Very often, high class dancing couples are also pairs in life (Brewińska \& Poczwardowski, 2010). In the years $1990-2000,37 \%$ of pair medallists and $30 \%$ of ice dance medallists at the world championships were either married or engaged to be married. Fisher and Adams (1994) stated that: "These relationships are not merely friendships, they are friendships that are extremely close - as in the case of best friends. These relationships often (but not necessarily) include marital spouses and some family or kinship relations between, for example brothers and sisters or parents and children" (Fisher \& Adams, 1994, p. 392).

It seems accurate to surmise that as a couple's relationship progresses, the commitment moves from being specific to the sport to encompassing all other dimensions of the relationship. The time and amount of training have to be fitted to both persons in a couple. Every dancer has to adapt his personal life to his dance partner. In consequence, dancers get to know each other more; they do not meet and talk only in the training hall, but share each other's plans and personal life. The common seeking of solutions and compromises builds trust and more involvement. The more they know about their partner, the more things they find they have in common, not only in the field of dance, but also in the personal character of both athletes. The greater commitment in the sport and personal life makes the relationship in the couple more intense. The strong relationship and common goal, which both dancers in the couple share, leads to good cooperation and also sport success.

Another common highly valued variable was trust in the couple (women: $r=.54$, men: $r=.59$ ). In Wanlin's (1998, p. 5) study of a young ice dancing couple, the participants stated: "You have to have $100 \%$ trust, good communication skills, and you have to be in tune with the other person, know what the other person is thinking”. Trust is believed to be an important component of secure attachments, not only in sport. Johnson and Talisman (1996) found that trust was an important component related to success of therapy and marital satisfaction.

The next common variable was satisfaction with progress - although for women the correlation was stronger $(r=.63)$ than for men $(r=.43)$, and was more statistically significant. Another common variable was the partner's involvement in the development of the couple. However, for women, this factor was the most important $(r=.68)$, whereas for men it was important but with the lowest correlation $(r=.37)$. This may mean that women will be more satisfied with a dance couple if partners try harder in training.

Dance partners similarly assessed the value of their own involvement in the development of the couple (correlation for women $r=.43$, for men $r=.37$ ), so they hold themselves to high requirements when it comes to developing a dance couple. Similar conclusions were drawn by Martens (1970), who found that teams that were high in task motivation were more successful and satisfied than those teams that were low in task motivation. A number of subsequent studies have found similar results (e.g., Arnold \& Straub, 1972; Carron, Ball, \& Chelludurai, 1977; Widmeyer, 1977).

The partners of both sexes believe that own responsibility for the development of a couple is not related to satisfaction. This is quite a surprising result, which could mean that partners still need more experience. For men, partner's responsibility for the development of the couple reached the highest value, while for women this correlation was non-significant. It appears, therefore, that men attach great importance to how their partner takes care of a dance couple. An interesting fact is that in the case of women there occurred no correlation of satisfaction in the couple with the responsibility for the development of the couple, both own and partner's.

The analysis of regression showed that subjective variables explain $62 \%$ of variance of satisfaction in the couple for women and $64 \%$ for men. Objective variables seem to be significant only for women, and they explain $26 \%$ of the whole variance of satisfaction. The significant predictor for women is satisfaction with progress, while for men it is the responsibility for the development of the couple, both own and partner's. Ballroom dancing seems to have a lot in common with the functioning of the partnership and at the same time functioning in a sport team. Carron (1988) proposed that a sport team represents a special type of group. These are characterized by "a collective identity, a sense of shared purpose, structured patterns of interaction, structured methods of communication, personal and task interdependence and interpersonal attractions" (p. 7). A good sports team is not formed from day to day - it is a process of formation of: interaction, commitment, trust, creating roles in order to achieve results and satisfaction that people are working in a cohesive team. A team can be described as two or more people who interact and influence one another within a specific structure, which leads to the formation of a bond among members (Unsworth \& West, 2003). Each member of the team may be responsible for a different part of the relationship and thereby achieve satisfaction from the cooperation in a different way. The results of the present study suggest that although women and men in pair dancing differ in the way of achieving satisfaction from the cooperation, they gain a similar level of contentment with working together. 
The present results may be helpful for coaches in building a work plan with dancers. Apart from the technical aspects, it should also include psychological factors (i.e. relation between partners) as relevant to the satisfaction of practising discipline and success in sport. One aspect that should not be underestimated when it comes to work with a sport team, in this case with dancers, should be continuous work on effective communication. Yukelson (1997) stated that effective communication is based on trust, honesty, mutual sharing and mutual understanding. If a group is to function effectively, members must be able to communicate openly and honestly with one another about the efficiency of group functioning and/or the quality of interpersonal relationships. According to the obtained results it is important for dance partners - the woman and the man - to communicate and be aware of differences in aspects that influence the satisfaction from cooperation for each of them. Regular team meetings to share information and process experiences is seen to increase the depth and creativity of decision-making, trust building, mutual respect and mutual understanding (Orlick, 1986; Yukelson, 1993).

A limitation of the study is the small number of participants as well as the large range of subjects' age. In the future it is planned to increase the group and its distribution in different age groups in order to analyse the changes taking place under the influence of practising the dance as well as any developmental changes in perception of satisfaction in the couple.

\section{CONCLUSIONS}

Satisfaction plays an important role in relationships. In sport, satisfaction may come from a number of factors such as success, social support, feelings of accomplishment and activity itself. Wanlin (2000) in research concerning ice dancing and pairs skating stated that satisfaction may be divided into two categories: 1) achievement and/or success (task) satisfaction, and 2) social satisfaction. Achievement satisfaction consists of enjoyment from performing competently, and social satisfaction refers to the enjoyment/satisfaction that athletes get from the relationship with their partners. Similar conclusions can be drawn from the current study.

\section{References}

Anshel, M. H. (1994). Sport psychology: From theory to practice $\left(2^{\text {nd }}\right.$ ed.). Scottsdale, AZ: Gorsuch Scarisbrick Publishers.

Arnold, G. E., \& Straub, W. F. (1972). Personality and group cohesiveness as determinants of success among inter-scholastic basketball teams. In: I. D. Williams, \& L. M. Wankel (eds.), Proceedings of the Fourth Canadian Symposium on Psycho-motor Learning and Sport Psychology (pp. 346-352). Ottawa, ON: Fitness and Amateur Sport Directorate, Department of National Health and Welfare.

Argyle, M., \& Henderson, M. (1984). The rules of friendship. Journal of Social and Personal Relationships, 1, 211-237.

Bednarzowa, B., \& Młodzikowska M. (1983). Tańce. Rytm. Ruch. Muzyka [Dances. Rhythm. Movement. Music]. Warszawa: Wydawnictwo Sport i Turystyka.

Brawley, L. R., \& Paskevich, D. M. (1997). Conducting team building research in the context of sport and exercise. Journal of Applied Sport Psychology, 9, 11-40.

Brewińska, A., \& Poczwardowski, A. (2012). Eksploracja pozytywnych elementów w relacjach interpersonalnych par sportowego tańca towarzyskiego: rezultaty badania jakościowego [Exploration of positive elements in sporting ballroom dancing couples' interpersonal relations: the results of qualitative research]. In: J. Blecharz, M. Siekańska, \& A. Tokarz (eds.), Optymalizacja treningu sportowego i zdrowotnego z perspektywy psychologii [Optimization of sports and health training from the perspective of psychology] (pp. 233-245). Kraków: Akademia Wychowania Fizycznego im. Bronisława Czecha.

Cahn, D. (1987). Letting go: A practical theory of relationship disengagement and reengagement. Albany NY: SUNY Press.

Carron, A. V., Ball, J. R., \& Chelludurai. P. (1977). Motivation for participation, success in performance and their relationship in individuals and group satisfaction. Perceptual and Motor Skills, 45, 835-841.

Carron, A. V. (1980). Social psychology of sport. Ithaca, NY: Movement.

Carron, A. V. (1988). Group dynamics in sport: Theoretical and practical issues. London, Ontario: Spodym Publishers.

Cole, T., \& Bradac, J. J. (1996). A lay theory of relational satisfaction with Best friends. Journal of Social and Personal Relationships, 13, 57-83.

Darwin, K. (1972). The Expression of Emotions in Man Animals. London: John Murray.

Eliade, M. (2009). Historia wierzeń i idei religijnych (Tom 1) [The history of religious ideas and beliefs (vol. 1)]. Warszawa: PAX.

Fincham, F. D., \& Bradbury, T. N. (1989). Perceived responsibility for marital events: egocentric or partner-centric bias? Journal of Marriage and the Family, 51, 27-35.

Fisher, B. A., \& Adams, K. L. (1994). Interpersonal communication: Pragmatics of human relationships. New York: McGraw-Hill Inc.

Fostiak, D. (1996). Koordynacja ruchowa u zawodników gimnastyki artystycznej, tyżwiarstwa figurowego i sportowego tańca towarzyskiego [Motor coordination of rhythmic gymnastics athletes, figure
Determinants of the satisfaction in a dance couple 
skating athletes and ballroom dancing athletes]. Gdańsk: Wydawnictwo Uczelniane AWF.

Hawes, L. C., \& Smith, D. H. (1973). A critique of assumptions underlying the study of communication in conflict. Quarterly Journal of Speech, 62, 423-435.

Johnson, S. M., \& Talisman, E. T. (1996). Predictors of success in emotionally focused marital therapy. Journal of Marital and Family Therapy, 23, 135-152.

Kaźmierczak, M. (2008). Oblicza empatii w relacjach matżeńskich. Perspektywa psychologiczna [Faces of empathy in marriage. Psychological perspective]. Gdańsk: Wydawnictwo Uniwersytetu Gdańskiego.

Kelley, H. H., \& Thibaut, J. W. (1978). Interpersonal relations: A theory of interdependence. New York: Wiley-Interscience.

Kelley, H. H. (1983). Love and commitment. In: H. H. Kelley, E. Berscheid, A. Christensen, J. H. Harvey, T. L. Huston, G. Levinger, E. McClintock, L. A. Peplau, \& D. R. Peterson (eds.), Close relationships (pp. 265-314). New York: W. H. Freeman.

Kram, K. E., \& Isabella, L. A. (1985). Mentoring alternatives: The role of peer relationships in career development. Academy of Management Journal, 28, 110-132.

Larzelere, R., \& Huston, T. (1980). The dyadic trust scale: Towards understanding interpersonal trust in close relationships. Journal of Marriage and the Family, 43, 595-604.

Martens, R. (1970). Influence of participation motivation on success and satisfaction in team performance. Research Quarterly, 41, 510-518.

Mears, P., \& Voehl, F. (1994). Team Building. A Structured Learning Approach. Delray Beach, FL: St Lucie Press.

Orlick, T. (1986). Psyching for sport. Champaign, IL: Human Kinetics.

Plopa, M. (2004). Psychologia rodziny. Teoria i badania [Psychology of family. Theory and research]. Elbląg: Wydawnictwo EUH-E.

Reisman, J. M. (1981). Adult friendships. In: S. Duck, \& R. Gilmour (eds.), Personal relationships 2: Developing personal relationships (pp. 205-230). New York: Academic Press.

Reuna, C., Weich, M., \& Zimmer, D. (1984). Evaluation of a communication skills training program with groups of people living together. In: K. Hahlweg, \& N. S. Jacobson (eds.), Marital interaction analysis and modificatio (pp. 105-112). New York, NY: The Guilford Press.

Rusbult, C. E. (1980). Commitment and satisfaction in romantic associations: A test of the investment model. Journal of Experimental Social Psychology, 16, 172-186.

Rusbult, C. E. (1983). A longitudinal test of the investment model: The development (and deterioration) of satisfaction and commitment in het- erosexual involvements. Journal of Personality and Social Psychology, 45, 101-117.

Scanlan, T. K., Carpenter, P. J., Schmidt, G. W., Simons, J. P., \& Keeler, B. (1993). An introduction to the sport commitment model. Journal of Sport \& Exercise Psychology, 15, 1-15.

Schmidt, G. W., \& Stein, G. L. (1991). Sport commitment: A model intergrating enjoyment, drop out, and burnout. Journal of Sport \& Exercise Psychology, 13, 254-265.

Sharabany, R. (1994). Intimate friendship scale: Conceptual underpinnings, psychometric properties and construct validity. Journal of Social and Personal Relationships, 11, 449-469.

Spencer, H. (1955). The Principles of Psychology. London: Routledge.

Sprecher, S. (1992). How men and women expect to feel and behave in response to inequity in close relationships. Social Psychology Quarterly, 55, 57-69.

Steiner, I. D. (1972). Group processes and group productivity. New York: Academic Press.

Tomaszewski, W. (1991). Człowiek tańczący [Man dancing]. Warszawa: Wydawnictwa Szkolne i Pedagogiczne.

Tremayne, P., \& Ballinger, A. D. (2008). Performance enhancement for ballroom dancers: Psychological perspectives. The Sport Psychologist, 22, 90-108.

Unsworth, K. L., \& West, M. A. (2003): Zespoły: wyzwania pracy w grupie [Teams: challenges of group work]. In: N. Chmiel (ed.), Psychologia pracy $w$ organizacji [Psychology of work in the organization] (pp. 359-380). Gdańsk: GWP.

Wanlin, C. M. (1998). Relationship issues in ice dancing: A preliminary investigation. Presentation at the Annual General Meeting of the American Psychological Association. San Fransisco, CA.

Wanlin, C. M. (2000). The Relationships between Communication, Trust, Success, Satisfaction, and Longevity in Ice Dancing and Pairs Skating. Dissertation submitted to the School of Physical Education At West Virginia University, Morgantown.

Widmeyer, W. N. (1977). When cohesiveness predicts outcome in sport. Unpublished doctoral dissertation. University of Illinois, Champaign, IL.

Yin Chu, A., \& Wang, Ch. (2012). Differences in the level of sport commitment among college Dance sport competitors. Social Behavior and Personality, 40, 755-766.

Yukelson, D. (1993). Communicating effectively. In: J. Williams (eds.), Applied sport psychology: Personal growth to peak performance (2nd ed.) (pp. 122136). Mountain View, CA: Mayfield Publishing.

Yukelson, D. (1997). Principles of effective team building interventions in sport: A direct services approach at Penn State University. Journal of Applied Sport Psychology, 9, 73-96. 


\section{APPENDIX}

\section{SURVEY (VERSION FOR DANCERS)}

We invite you to participate in research in the area of psychology of sport, whose objectives include increasing knowledge about the functioning of athletes and the impact of their passion / profession on the quality of life and relationships with others. Please complete the information below, provide the answers and/ or provide a brief description. Tests are anonymous, and the results will be presented without information enabling identification of the people involved in them.

1. Age:

2. Sex: F M

3. Dance class in

a. ST:

b. LA:

4. The competitive period in months or years:

5. The competitive period with the current partner in months or years:

6. Below a ladder is drawn. The bottom of the ladder represents the lowest satisfaction from cooperation in the couple which you could experience (score 0). The top represents the best cooperation in the couple which you could expect (score 10). Please circle the number on the ladder which represents the score of your satisfaction with the cooperation in the couple.

\begin{tabular}{|l|}
\hline 10 \\
\hline 9 \\
\hline 8 \\
\hline 7 \\
\hline 6 \\
\hline 5 \\
\hline 4 \\
\hline 3 \\
\hline 2 \\
\hline 1 \\
\hline
\end{tabular}

7. Please specify the relationship with a partner in the following manner. Each couple of circles represents a relationship between you and your partner. One circle represents you, while the other represents your partner. Please circle the number of the pair of circles that best describes how close you are to each other in the couple.
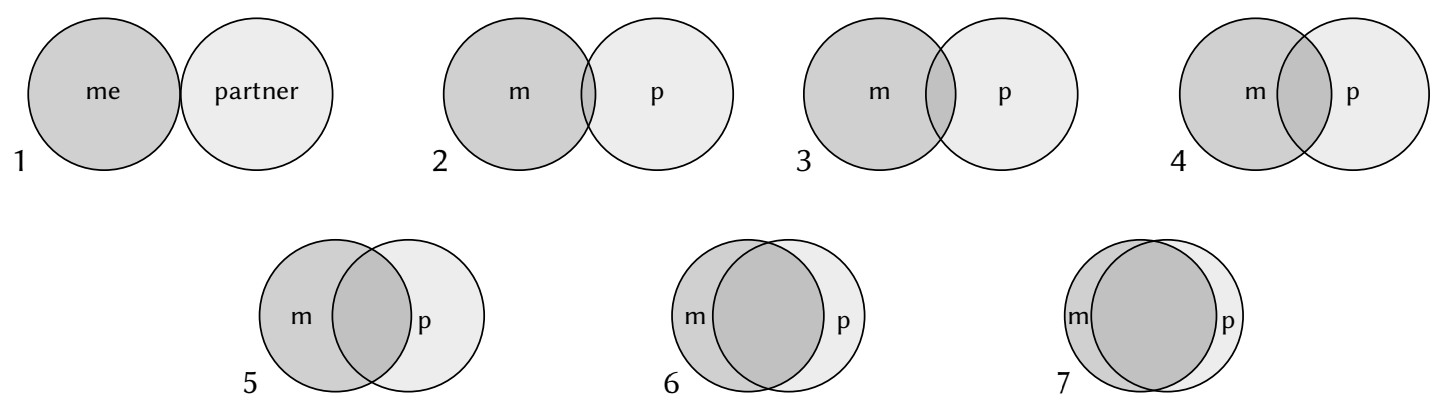

Determinants

of the satisfaction in a dance couple 
8. On the following scales, please mark:

a. the extent to which you are involved in the development of the dance couple

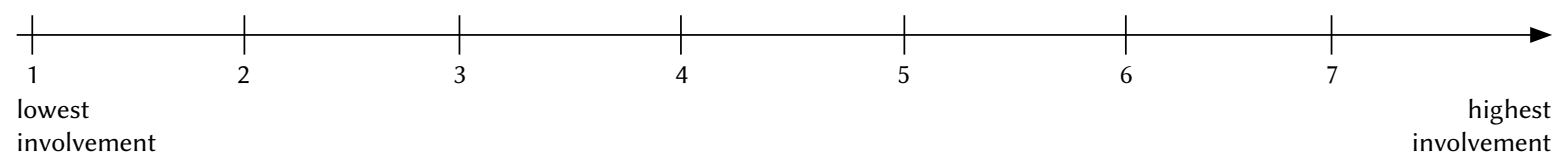

b. the extent to which your dance partner is involved in the development of the dance couple

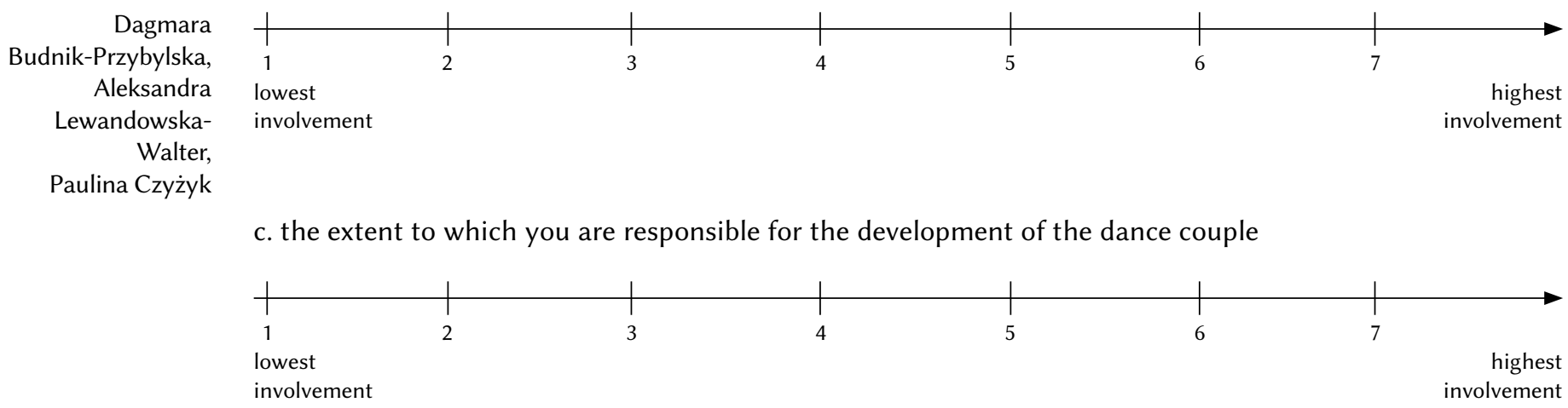

d. the extent to which your dance partner is responsible for the development of the dance couple

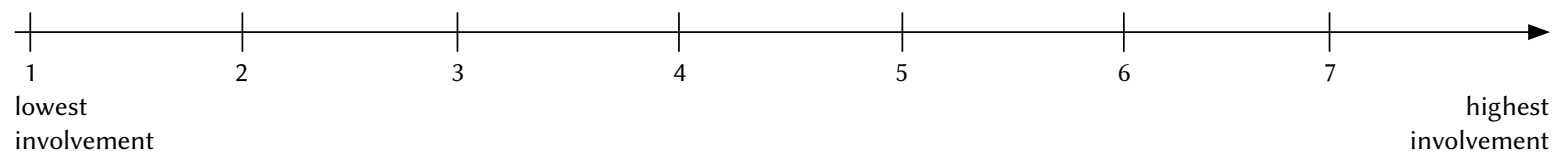

e. the extent to which you are satisfied with the sporting progress of the couple

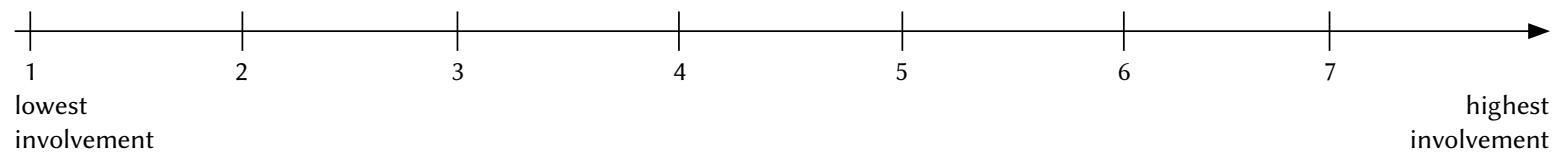

\section{TRUST SCALE IN THE COUPLE}

To what extent do you agree with the following statements considering your dance partner? On a scale of 1 to 7 , where 1 means "I completely disagree with this statement" and 7 means "I fully agree with this statement", please refer to the following statements. To select the appropriate answer, please circle the correct number. There are no right or wrong answers, because each person is different.

1. My partner is primarily interested in his own good.

2. There are periods when I can't trust my partner.

3. My partner is fully honest and sincere to me.

4. I feel that I can completely trust my partner.

5. My partner is fully sincere in his promises.

6. I feel that my partner is not paying me enough attention.

7. My partner doesn't treat me fairly and justly.

8. I feel that I can count on my partner.

$\begin{array}{lllllll}1 & 2 & 3 & 4 & 5 & 6 & 7 \\ 1 & 2 & 3 & 4 & 5 & 6 & 7 \\ 1 & 2 & 3 & 4 & 5 & 6 & 7 \\ 1 & 2 & 3 & 4 & 5 & 6 & 7 \\ 1 & 2 & 3 & 4 & 5 & 6 & 7 \\ 1 & 2 & 3 & 4 & 5 & 6 & 7 \\ 1 & 2 & 3 & 4 & 5 & 6 & 7 \\ 1 & 2 & 3 & 4 & 5 & 6 & 7\end{array}$

Thank you for your participation in the study, employees of the Institute of Psychology of the University of Gdansk. 